\title{
Interactions with Hosts at Cool Temperatures, Not Cold Tolerance, Explain the Unique Epidemiology of Ralstonia solanacearum Race 3 Biovar 2
}

\author{
Annett Milling, Fanhong Meng, Timothy P. Denny, and Caitilyn Allen
}

First, second, and fourth authors: Department of Plant Pathology, University of Wisconsin-Madison, Madison 53706; and third author: Department of Plant Pathology, University of Georgia, Athens 30603. Accepted for publication 15 May 2009.

\begin{abstract}
Milling, A., Meng, F., Denny, T. P., and Allen, C. 2009. Interactions with hosts at cool temperatures, not cold tolerance, explain the unique epidemiology of Ralstonia solanacearum race 3 biovar 2. Phytopathology 99:1127-1134.

Most strains of the bacterial wilt pathogen Ralstonia solanacearum are tropical, but race 3 biovar 2 (R3bv2) strains can attack plants in temperate zones and tropical highlands. The basis of this distinctive ecological trait is not understood. We compared the survival of tropical, R3bv2, and warm-temperate North American strains of $R$. solanacearum under different conditions. In water at $4^{\circ} \mathrm{C}$, North American strains remained culturable the longest (up to 90 days), whereas tropical strains remained

indicated that cells of representative strains remained viable for $>160$ days. In contrast, inside potato tubers, R3bv2 strain UW551 survived $>4$ months at $4{ }^{\circ} \mathrm{C}$, whereas North American strain K60 and tropical strain GMI1000 were undetectable after $<70$ days in tubers. GMI1000 and UW551 grew similarly in minimal medium at 20 and $28^{\circ} \mathrm{C}$ and, although both strains wilted tomato plants rapidly at $28^{\circ} \mathrm{C}$, UW551 was much more virulent at $20^{\circ} \mathrm{C}$, killing all inoculated plants under conditions where GMI100 killed just over half. Thus, differences among the strains in the absence of a plant host were not predictive of their behavior in planta at cooler temperatures. These data indicate that interaction with plants is required for expression of the temperate epidemiological trait of R3bv2.
\end{abstract} culturable for the shortest time ( $\approx 40$ days). However, live/dead staining
The ability to persist in an environment is critical for pathogen success. Determining an exotic phytopathogen's potential to survive the conditions in a new region is one important step in predicting whether it could become established there and pose a long-term threat to crops. In addition, understanding the biological mechanisms underlying pathogen persistence in an environment can suggest effective methods of exclusion and control.

Brown rot of potato, also known as bacterial wilt, is caused by a subgroup of Ralstonia solanacearum known as race 3 biovar 2 (R3bv2) $(1,23)$. Brown rot is among the most serious diseases of potato worldwide, causing an estimated $\$ 950$ million in losses each year (12). The disease is a major constraint to production in the tropical highlands of South America, Africa, and Asia but it is also present in Europe, the Middle East, and Australia (12,35). In addition to potato, R3bv2 also infects tomato, eggplant, geranium, and many weeds and wild plants $(13,26,34,49,55)$. The bacterium has been accidentally introduced to North America and Europe on infected geranium cuttings imported from the highland tropics where R3bv2 is endemic $(26,30,42,44,56)$ but it does not appear to have become established in North America.

$R$. solanacearum $\mathrm{R} 3 \mathrm{bv} 2$ is transmitted via infected plant material, soil, or surface water. The bacterium invades plants through wounds and colonizes the host xylem tissue, causing wilting, tuber rot, and plant death. R3bv2 often forms symptomless, or latent, infections that facilitate unknowing pathogen spread in seed potato tubers or plant cuttings $(1,45)$. R3bv2 probably originated in the Andes with potato, and isolates from around the world are nearly genetically and phenotypically identi-

Corresponding author: C. Allen; E-mail address: cza@plantpath.wisc.edu

doi:10.1094/PHYTO-99-10-1127

(C) 2009 The American Phytopathological Society cal, suggesting that it was distributed from South America in potato tubers $(14,24,41,50)$. Like other strains from the Americas, R3bv2 belongs to the phylotype II subspecies division of the $R$. solanacearum species complex, and is further subclassified in sequevar 1 (14).

Most strains of $R$. solanacearum are tropical or subtropical, and many of these can wilt potato. However, field experiments and observations have documented the ability of R3bv2 to wilt potato plants at cooler temperatures than tropical or subtropical $R$. solanacearum strains $(6,7,47,48)$. R3bv2 has also frequently been described as cold tolerant $(15,23,43)$. However, it is not known if these differences reflect a greater ability of R3bv2 to survive in the environment at cold temperatures or, alternatively, more effective infection and wilting of plants under cool conditions. Epidemiological studies are contradictory regarding the ability of R3bv2 to survive cool conditions away from plants. In Australia, R3bv2 survived $>2$ years in bare fallow soils with an average winter temperature of $4^{\circ} \mathrm{C}(40)$. In contrast, although R3bv 2 cells remained viable up to a year in field soils in the Netherlands at $12^{\circ} \mathrm{C}$, at $4^{\circ} \mathrm{C}$, the pathogen became undetectable after only a month (52). Similarly, R3bv2 cells could not be detected after a month in Dutch irrigation water at $4^{\circ} \mathrm{C}(51)$. Nevertheless, it has proven difficult to eradicate R3bv2 from northern Europe, where the pathogen may survive and multiply in alternative hosts, especially the semiaquatic weed bittersweet nightshade, Solanum dulcamara (11).

R3bv2 is a quarantine pathogen in Europe and North America, and is listed as a Select Agent in the United States (31). Although non-R3bv2 strains of $R$. solanacearum that can infect and wilt potato are endemic and widespread in the southeastern United States, these native strains have never become established north of the mid-Atlantic states. Regulators consider that R3bv2 poses a potentially severe threat to the American potato industry because 
it may be able to overwinter and become established in soils and waterways of the primary potato-growing regions in the northern states.

Therefore, we designed experiments to determine whether R3bv2 strains have a unique ability to persist in the environment at cold temperatures relative to native North American and tropical $R$. solanacearum strains. We further sought to quantify the relative virulence and survival of tropical and R3bv2 strains in host plants at cool temperatures.

\section{MATERIALS AND METHODS}

Bacterial strains and growth conditions. $R$. solanacearum strains used in these experiments are listed and described in Table 1. Strains not previously subclassified were subclassified into phylotype and sequevar using the multiplex-polymerase chain reaction (PCR) phylotyping method followed by amplification and sequencing of the 750-bp internal fragment of the egl locus as described (14). All $R$. solanacearum strains were streaked onto casamino acids-peptone-glucose (CPG) solid medium (25) from $-80^{\circ} \mathrm{C}$ glycerol stocks or room-temperature water stocks and grown at $28^{\circ} \mathrm{C}$ for $48 \mathrm{~h}$. If required to select a rifampin-resistant mutant strain, rifampicin was added at a final concentration of $25 \mathrm{mg} / \mathrm{liter}$. Growth medium components were purchased from Difco Laboratories (Detroit). All other chemicals and antibiotics were purchased from Sigma-Aldrich (St. Louis).

Culturability and viability of bacterial cells in cold water. The effect of low temperatures on the survival of diverse $R$. solanacearum strains was determined in water microcosms maintained at $4{ }^{\circ} \mathrm{C}$. Bacterial strains were streaked onto CPG agar for $48 \mathrm{~h}$ to obtain single colonies which were transferred into CPG broth and grown at $28^{\circ} \mathrm{C}$ with shaking at $225 \mathrm{rpm}$ for 14 to $18 \mathrm{~h}$ to exponential growth phase (optical density at $600 \mathrm{~nm}$ $\left.\left[\mathrm{OD}_{600}\right]=0.1\right)$. Cells were pelleted by centrifugation at $2,500 \times g$ for $5 \mathrm{~min}$ and washed twice with room-temperature ultrapure water $(>18.2 \mathrm{mOhm})$. Water microcosms were prepared by transferring exponentially grown and washed cells into duplicate glass tubes $(18$ by $150 \mathrm{~mm}$ ) filled with $10 \mathrm{ml}$ of ultrapure water, establishing final cell densities of 1 to $2 \times 10^{7} \mathrm{CFU} / \mathrm{ml}$. After an initial incubation at room temperature for $48 \mathrm{~h}$, tubes were stored at $4^{\circ} \mathrm{C}$ without shaking. Samples were taken weekly from each tube and enumerated by serial dilution plating on CPG agar plates. Colonies on plates were counted after 36 to $48 \mathrm{~h}$ of incubation. To determine the proportion of cells that grew only in the presence of catalase, strains K60, GMI1000, and UW551 were dilution plated on CPG plates either amended or not amended by spreading 100 units of catalase (MP Biomedicals, Solon, $\mathrm{OH}$ ) per milliliter onto the agar surface shortly before use.
The detection limit was $1 \log \mathrm{CFU} / \mathrm{ml}$ and a value of $1 \log$ $\mathrm{CFU} / \mathrm{ml}$ was also used to report samples below the detection limit. Each experiment contained two independent water microcosms (replicates) per bacterial strain. These microcosms were sampled successively at each time point by dilution plating in triplicate (subsamples). The experiments were repeated three times.

In parallel, viable cells of $R$. solanacearum strains K60, GMI1000, and UW551 from the same water microcosms were enumerated with a live/dead bacterial viability kit (BacLight; Invitrogen, Carlsbad, CA) according to the manufacturer's instructions. The SYTO 9 stain labels all bacteria whether the cell membrane is intact or damaged, resulting in green fluorescent cells. In contrast, propidium iodide (PI) penetrates only bacteria with compromised membranes, reducing SYTO 9 stain fluorescence when both dyes are present and resulting in red fluorescent cells. Thus, green-fluorescing cells are considered viable and red-fluorescing cells are considered dead. Cells were collected on black polycarbonate membrane filters $(0.22 \mu \mathrm{m}$; GE Water \& Process Technologies, Trevose, PA) and enumerated by epifluorescence microscopy at a magnification of $\times 1,000$. At least 10 random fields containing, in total, 500 to 1,000 cells per sample, were scored. Total numbers of culturable and viable cells were determined in triplicate experiments.

After 154 days at $4^{\circ} \mathrm{C}$, water microcosms containing viable but nonculturable (VBNC) cells of K60, GMI1000, and UW551 $(50 \mathrm{ml})$ were used to inoculate unwounded 21-day-old susceptible tomato plants of cv. Bonny Best via a soil-soak inoculation (46). Briefly, 14-day-old tomato plants were transplanted into $10-\mathrm{cm}-$ diameter pots with $80 \mathrm{~g}$ of soil. Plants were inoculated by pouring a bacterial suspension onto the soil. Plants were monitored daily for disease progress by a rater who did not know which treatment each plant had been given, and symptoms were scored on a 0 to 4 disease index where 0 indicates no disease, 1 indicates 1 to $25 \%$ of leaves wilted, 2 indicates 25 to $50 \%$ of leaves wilted, 3 indicates 51 to $75 \%$ of leaves wilted, and 4 indicates 76 to $100 \%$ of leaves wilted. Twelve tomato plants were inoculated with water from individual microcosms for each strain. Plants were kept at $28^{\circ} \mathrm{C}$ and monitored daily for disease symptoms. Sixteen days after inoculation, tomato stem tissue samples were ground in sterile ultrapure water and tested with $R$. solanacearum-specific immunostrips (Agdia Inc., Elkhart, IN) for the presence of the pathogen in planta and were also plated on CPG agar. Plates were checked for the presence of colonies after $48 \mathrm{~h}$ of incubation at $28^{\circ} \mathrm{C}$.

Survival in potato tubers. We measured the survival of $R$. solanacearum strains K60, GMI1000, and UW551 in susceptible potato minituber (Sklarczyk Seed Farm, Johannesburg, MI) cvs.

TABLE 1. Ralstonia solanacearum strains used in this research

\begin{tabular}{|c|c|c|c|c|c|c|c|}
\hline Group $^{\mathrm{a}}$ & Strain & Race & Biovar & Phylotype or sequevarb & Isolated from & Location & Source \\
\hline A & $\mathrm{K} 60^{\mathrm{c}}$ & 1 & 1 & II/7 & Tomato & North Carolina, United States & 29 \\
\hline A & AW1 & 1 & 1 & $\mathrm{II} / 7$ & Tomato & Alabama, United States & 9 \\
\hline A & UW27 & 1 & 1 & $\mathrm{II} / 7$ & Tobacco & Florida, United States & C. Allen \\
\hline A & UW576 (= Rs5) & 1 & 1 & $\mathrm{II} / 7$ & Tomato & Florida, United States & 27 \\
\hline B & UW551 & 3 & 2 & II/1 & Geranium & Wisconsin, United States & 46 \\
\hline B & IPO1609 & 3 & 2 & II/1 & Potato & The Netherlands & 53 \\
\hline B & UW260 & 3 & 2 & II/1 & Potato & Cajamarca Chota, Peru & C. Allen \\
\hline B & UW276 & 3 & 2 & II/1 & Potato & Mexico & C. Allen \\
\hline B & UW492 & 3 & 2 & II/1 & Potato & San Ramon, Peru & C. Allen \\
\hline $\mathrm{C}$ & UW582 (= Rs120) & 1 & 1 & $\mathrm{II} / 5$ & Hydrangea & Florida, United States & 27 \\
\hline $\mathrm{C}$ & GMI $1000^{c}$ & 1 & 3 & $\mathrm{I} / 18$ & Tomato & French Guyana & 4 \\
\hline $\mathrm{C}$ & UW585 (= Rs123) & 1 & 3 & $\mathrm{I} / 13$ & Pepper & Florida, United States & 27 \\
\hline $\mathrm{C}$ & UW568 & 1 & 3 & $\mathrm{I} / 14$ & Soil, tomato field & Guatemala & 38 \\
\hline
\end{tabular}

a Groups A, B, and $\mathrm{C}$ were distinguished based on relative survival in $4^{\circ} \mathrm{C}$ water.

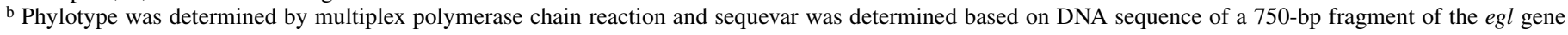
as described by Fegan and Prior (14).

c Spontaneous rifampicin-resistant variants K60-rif, UW551-rif, and GMI1000-rif were used in potato tuber survival studies. 
Russet Norkotah (15 to $17 \mathrm{~mm}$ in diameter) and Shepody (18 to $24 \mathrm{~mm}$ in diameter) at $4^{\circ} \mathrm{C}$. All three strains tested were capable of wilting potato plants (data not shown). Experiments were performed with rifampicin-resistant $R$. solanacearum strains to facilitate pathogen detection in the natural microbial background. Spontaneous rifampicin-resistant K60 (K60-rif) grows in culture and in planta and causes a wilt of tomato plants indistinguishable from that caused by the wild-type parent strain (45). Natural transformation (28) was used to transfer the rifampicin resistance from K60-rif into strains UW551 and GMI1000; briefly, washed cells of each recipient strain were incubated with total DNA from K60-rif for $24 \mathrm{~h}$ and transformants were selected on CPG plates containing rifampicin. The wild-type virulence of the resulting rifampicin-resistant strains was confirmed.

Cultures grown to exponential phase and washed as described above were directly injected into potato tubers. A needle was inserted $\approx 0.5 \mathrm{~cm}$ deep into the tuber and $2 \mu \mathrm{l}$ of a $1 \times 10^{9} \mathrm{CFU} / \mathrm{ml}$ suspension were injected into each tuber with a long $10-\mu$ pipette tip, generating final cell densities of 1 to $2 \times 10^{6} \mathrm{CFU} / \mathrm{g}$ tuber. Two inoculations per tuber were made and inoculation sites were marked. Tubers were stored at $4^{\circ} \mathrm{C}$ in the dark and sampled destructively at intervals with a no. 5 cork borer by removing a cylinder of tissue $(0.5$ to $1 \mathrm{~cm}$ long, $\approx 0.3 \mathrm{~g})$ containing the inoculation site. Tissue was ground in sterile deionized water $(1: 10$ dilution). Serial dilutions were plated onto CPG agar plates containing rifampin at $25 \mathrm{mg} / \mathrm{liter}$ and cycloheximide at $100 \mathrm{mg} / \mathrm{liter}$ and colonies were counted after $48 \mathrm{~h}$ of incubation at $28^{\circ} \mathrm{C}$. Survival rates were calculated based on duplicate experiments for each potato cultivar using two to three individual tubers per sampling time point. The detection limit was $1 \log \mathrm{CFU} / \mathrm{g}$ potato tissue and a value of $1 \log \mathrm{CFU} / \mathrm{g}$ was also used to report samples below the detection limit.

To resuscitate and allow bacteria to multiply after culturable cells could no longer be detected on CPG agar plates, $0.5 \mathrm{~g}$ of potato tuber tissue was transferred to $4.5 \mathrm{ml}$ of CPG broth supplemented with filter-sterilized solutions of polymyxin B sulfate at $100 \mathrm{mg} / \mathrm{ml}$, bacitracin at $25 \mathrm{mg} / \mathrm{ml}$, penicillin-G at $0.5 \mathrm{mg} / \mathrm{ml}$, chloramphenicol at $5 \mathrm{mg} / \mathrm{ml}, 2,3,5$,-triphenyl tetrazolium chloride, cycloheximide at $100 \mathrm{mg} / \mathrm{ml}$, and rifampicin at $25 \mathrm{mg} / \mathrm{ml}$ and incubated with shaking at $28^{\circ} \mathrm{C}$ for $72 \mathrm{~h}$. This enrichment broth was then tested with $R$. solanacearum-specific immunostrips for the presence of the pathogen. In addition, broth was plated on CPG agar plates amended with rifampicin and with or without catalase. Enrichment broth $(10 \mu \mathrm{l})$ was also directly injected into the stem tissue of 21-day-old Bonny Best tomato plants between the cotyledons and the first true leaf. Plants were kept at $28^{\circ} \mathrm{C}$ and monitored daily for disease symptoms. Two weeks after inoculation, stem tissue samples from near the inoculation site were ground in sterile ultrapure water, serially diluted, and plated on CPG agar containing rifampicin. Plates were checked for the presence of colonies after $48 \mathrm{~h}$ of incubation at $28^{\circ} \mathrm{C}$. Tissue from three tubers per treatment (strain) was cultured in enrichment broth after 128 and 197 days at $4^{\circ} \mathrm{C}$; three tomato plants were stem-inoculated with broth from each enrichment tube. Dilution platings were conducted in triplicate for each subsample.

Growth curves. Growth rates of $R$. solanacearum strains UW551 and GMI1000 were compared in Boucher's minimal medium (BMM) (4) at $20^{\circ} \mathrm{C}$, a typical temperature in cool temperate or highland tropical potato fields, and at $28^{\circ} \mathrm{C}$, which is more typical of tropical agriculture. For each experiment, a single colony grown from a frozen stock was inoculated into CPG broth and grown at $28^{\circ} \mathrm{C}$ overnight with shaking $(225 \mathrm{rpm})$. This overnight culture was pelleted and washed twice with sterile deionized water, then used to inoculate a 125 -ml flask containing $30 \mathrm{ml}$ of prechilled $\left(20^{\circ} \mathrm{C}\right)$ or prewarmed $\left(28^{\circ} \mathrm{C}\right) \mathrm{BMM}$ plus $0.2 \%$ glucose to a starting $\mathrm{OD}_{600}$ of 0.02 for $28^{\circ} \mathrm{C}$ and 0.08 for $20^{\circ} \mathrm{C}$. CFU counts were determined by dilution plating on CPG agar plates every $12 \mathrm{~h}$ for cells grown at $28^{\circ} \mathrm{C}$ and every $24 \mathrm{~h}$ for cells grown at $20^{\circ} \mathrm{C}$. Each experiment contained three flasks per strain at each temperature, and experiments were repeated at least three times.

Virulence assays. To compare the virulence of $R$. solanacearum strains GMI1000 and UW551 at different temperatures, we used a naturalistic soil soak inoculation as described above (46), except that half the plants were moved from 28 to $20^{\circ} \mathrm{C}$ growth chambers 1 day after transplanting, and plants were inoculated with either UW551 or GMI1000 by pouring a bacterial suspension onto the soil to a final density of $\approx 1 \times 10^{8} \mathrm{CFU} / \mathrm{g}$ of soil. Each experiment contained a minimum of 20 plants per strain at each temperature, and experiments were repeated at least three times.

Statistical analysis. Data were tested for statistical significance of differences using the JMP 7.0.2 software package (SAS Institute, Cary, NC). For survival experiments in water microcosms, potato tubers, and the growth of the pathogen in liquid medium, log-transformed data of culturable $R$. solanacearum cells were analyzed by using mean values to perform an analysis of variance (ANOVA). For relative virulence of strains on tomato plants, mean disease indices from three independent replicates were analyzed. Because of the serial nature of sampling, we applied repeated measures ANOVA to analyze the results of experiments on survival in water, growth in culture, and disease progress. Factors considered for the analysis included bacterial strain, temperature, replicate, potato cultivar, and time of incubation. We assessed the significance of differences among strains and groups using $F$ statistics.

\section{RESULTS}

Culturability and viability of bacterial cells in water microcosms. Based on relative cold tolerance, we distinguished three groups of strains (Fig. 1). There were significant differences $(P=0.0054)$ in survival at $4^{\circ} \mathrm{C}$ between all three groups. The clustering of groups $\mathrm{A}, \mathrm{B}$, and $\mathrm{C}$ was repeatable and independent of experimental conditions; we observed the same groupings in

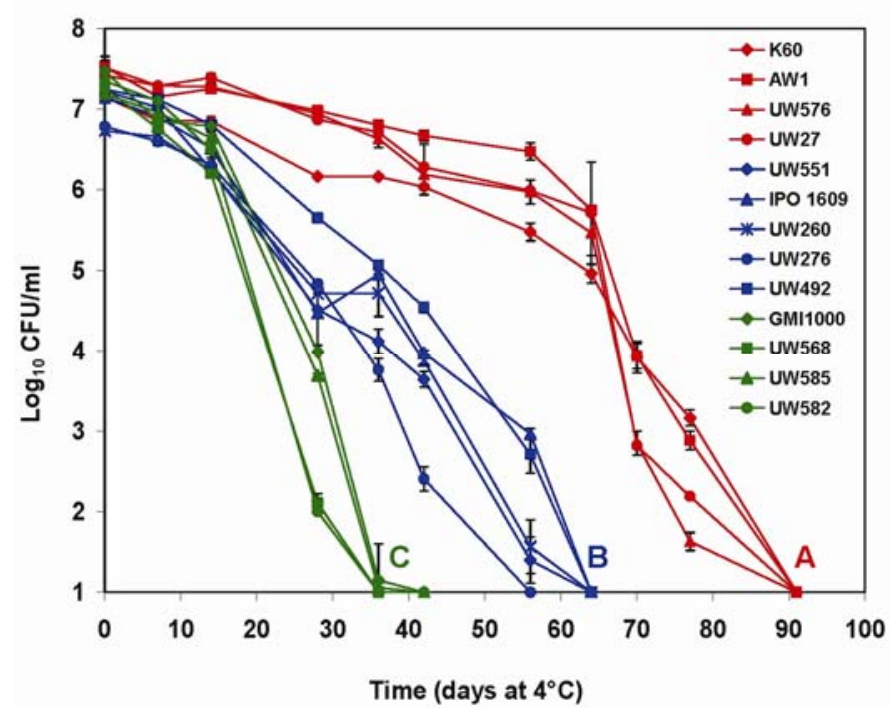

Fig. 1. Survival of diverse Ralstonia solanacearum strains in water at $4^{\circ} \mathrm{C}$. Cells were starved for 2 days at room temperature before incubation at $4^{\circ} \mathrm{C}$. Water microcosms were initially inoculated with $1 \times 10^{7} \mathrm{CFU} / \mathrm{ml}$. Culturable cells were enumerated at regular intervals by dilution plating on casamino acids-peptone-glucose agar plates. Strains clustered into groups A, B, and C based on relative survival. This experiment was repeated three times; typical results are shown. Each experiment contained two replicates, each containing three subsamples. Points represent means of all subsamples; bars indicate standard error. 
experiments using both $\log$ phase and stationary phase cells (data not shown). Group A, which consistently survived longest in water at $4^{\circ} \mathrm{C}$ compared with the other strains tested, included phylotype II, sequevar 7 (race 1, biovar 1 strains that originated in the southeastern United States). The viable cell counts of group A strains on unamended CPG plates declined to undetectable levels within 91 days. Group B, containing R3bv2 strains isolated from around the world, displayed an intermediate in vitro cold survival phenotype. Their culturable CFU counts dropped below the detection limit within 56 to 70 days of storage at $4^{\circ} \mathrm{C}$. However, the group B R3bv2 strains survived cold water better than group C strains, which belong to phylogenetic groups that originated in tropical Asia and the Caribbean (Table 1). Group C strains were most sensitive to $4^{\circ} \mathrm{C}$ in water and their CFU counts dropped

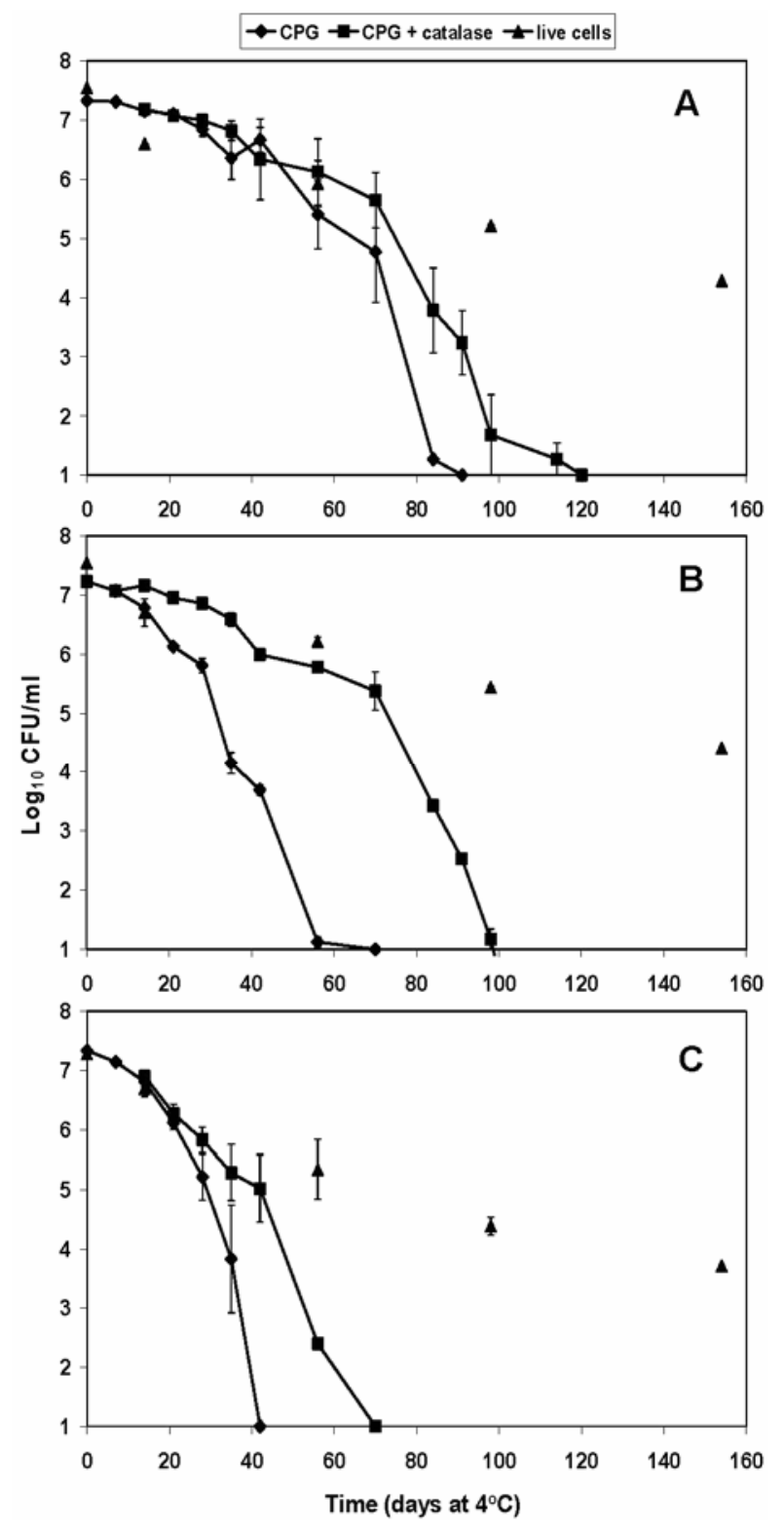

Fig. 2. Ralstonia solanacearum cells become viable but nonculturable over time in water at $4^{\circ} \mathrm{C}$. Water microcosms were inoculated with $\mathbf{A}$, endemic North American strain K60; B, race 3 biovar 2 strain UW551; or C, tropical strain GMI1000 at $1 \times 10^{7} \mathrm{CFU} / \mathrm{ml}$. Cells were starved for 2 days at room temperature before incubation at $4^{\circ} \mathrm{C}$. Culturable cells were enumerated at regular intervals by dilution plating on casamino acids-peptone-glucose agar plates with and without catalase. The live/dead stain was used to enumerate viable cells via epifluorescence microscopy. This experiment was repeated three times; typical results are shown. Each experiment contained two replicates, each containing three subsamples. Points represent means of all subsamples; bars indicate standard error. rapidly. No culturable group $\mathrm{C}$ bacteria could be recovered after 36 to 42 days. Subsequent experiments focused on one representative strain from each group: the $R$. solanacearum type strain K60 from group A; R3bv2 strain UW551 from group B, because it is well characterized and has been sequenced (16); and GMI1000 from group C, because its genome has also been sequenced (37).

Catalase amendment of plates dramatically increased the culturability of cold-treated $R$. solanacearum cells in all three groups (Fig. 2). At the beginning of each experiment, microcosm cell counts were the same on CPG plates with and without catalase but, as cells were stored at $4^{\circ} \mathrm{C}$, colony counts on unsupplemented plates dropped faster than those on catalase-containing plates for all strains $(P<0.0001)$. After cell counts on $\mathrm{CPG}$ without catalase dropped below a threshold of $\log 1 \mathrm{CFU} / \mathrm{ml}$, the CFU counts on catalase-containing plates were $10^{3}$ to $10^{5}$-fold greater, depending on the strain. Culturable K60 cells (group A) formed colonies on catalase-containing plates after up to 120 days at $4{ }^{\circ} \mathrm{C}$, although colonies were undetectable on unamended $\mathrm{CPG}$ media after 91 days. Similarly, cells of strain UW551 (group B) were culturable in the presence of catalase up to 98 days but for only 70 days without it. CFU counts for cold-sensitive tropical strain GMI1000 (group C) remained detectable on catalasecontaining media until 70 days at $4{ }^{\circ} \mathrm{C}$ storage but dropped below detection limits on CPG without catalase after just 42 days.

As expected, total cell numbers in water microcosms (live plus dead) remained stable (data not shown). Apparently, living cells of all three strains tested were present long after colonies no longer formed on plates. Even after 154 days in water at $4^{\circ} \mathrm{C}$, water microcosms still contained between $2 \times 10^{4}$ and $3 \times 10^{5}$ cells with intact membranes per milliliter (Fig. 2). These results suggest that incubation at $4^{\circ} \mathrm{C}$ in water causes $R$. solanacearum cells from diverse strains to go into a VBNC state. The VBNC cells of K60, UW551, and GMI1000 that were present after 154 days at $4{ }^{\circ} \mathrm{C}$ could not wilt tomato plants following soil-soak inoculation. Neither GMI1000 nor UW551 could be detected in inoculated tomato plants with immunostrips specific for $R$. solanacearum, which have a detection limit of $10^{5}$ cells. However, the strip test did detect K60 in tomato midstem tissue from 7 of 12 inoculated plants 16 days after the tomato plants were inoculated with water containing VBNC cells, indicating that $R$. solanacearum cells had entered, spread, and multiplied in these plants. Nonetheless, no inoculated plant showed wilt symptoms. Furthermore, no CFU were recovered from any inoculated plants when ground stem tissue was plated on CPG with or without catalase, suggesting that, although the K60 cells could multiply in planta, they were in an irreversible state of nonculturability.

Survival in potato tubers. We also compared survival in potato minitubers of three representative $R$. solanacearum strains. At $4^{\circ} \mathrm{C}$, a typical temperature for commercial seed potato storage, culturable cells of R3b2 strain UW551 could be detected by growth on plates significantly longer $(P<0.0001)$ than cells of either tropical strain GMI1000 (group C) or American strain K60 (group A) (Fig. 3). Four months after inoculation, we could still detect UW551 in potato tubers, whereas K60 and GMI1000 dropped to undetectable numbers less than 70 days after tuber inoculation. All three strains survived comparably in cvs. Russett Norkotah and Shepody, suggesting that potato cultivar did not influence survival of $R$. solanacearum at low temperatures.

Up to 6 months after tuber inoculation, cells of all three strains could still be recovered after but not before $72 \mathrm{~h}$ of enrichment culture of potato tissue as detected by $R$. solanacearum-specific immunostrips with a detection limit of $10^{5} \mathrm{CFU}$ (45). This result suggests that $R$. solanacearum cells had either moved into a reversible VBNC state during storage in potato tubers or had fallen below our detection threshold. After 128 days at $4{ }^{\circ} \mathrm{C}$, all three strains multiplied in tomato stems injected with enrichment broth from stored tubers. Strains K60 and GMI1000 reached populations in planta of $1 \times 10^{9} \mathrm{CFU} / \mathrm{g}$ of stem tissue but, al- 
though culturable, these strains appeared to be nonvirulent because no inoculated tomato plants wilted. In contrast, UW551 reached average cell densities of $1 \times 10^{10} \mathrm{CFU} / \mathrm{g}$ following inoculation and caused severe wilting symptoms in $60 \%$ of plants. However, after 197 days in tubers at $4^{\circ} \mathrm{C}$, none of the three strains could be recovered by enrichment broth culture or subsequent plant inoculation.

Tropical and R3bv2 strains grew similarly in culture at 20 and $28^{\circ} \mathbf{C}$. There was no difference in growth rate between the two strains at $28^{\circ} \mathrm{C}(P=0.293)$ (Table 2$)$. Both strains reached stationary phase after $\approx 48 \mathrm{~h}$, with peak cell density at $60 \mathrm{~h}$ (Fig. $4 \mathrm{~A})$. The overall time course of growth for UW551 and GMI1000 were also quite similar at $20^{\circ} \mathrm{C}$, where both strains grew more slowly even though the starting cell density was higher than for the $28^{\circ} \mathrm{C}$ cultures, reaching maximum cell density at $168 \mathrm{~h}$ (Fig. $4 \mathrm{~B})$. In the second half of the $20^{\circ} \mathrm{C}$ growth curve, after $72 \mathrm{~h}$, UW551 cell density was approximately twofold higher than that of GMI1000. This difference, although small, was reproducible and significant $(P=0.0034)$. Maximum cell densities in minimal medium for UW551 at $20^{\circ} \mathrm{C}$ were comparable with those of UW551 and GMI1000 at $28^{\circ} \mathrm{C}(P>0.0001)$.

R3bv2 was much more virulent at $20^{\circ} \mathrm{C}$ than a tropical strain. In a soil-soak inoculation of unwounded susceptible tomato plants, both GMI1000 and UW551 were highly virulent at $28^{\circ} \mathrm{C}$ (Fig. 5). In all, 94\% of inoculated plants were dead by 16 days postinoculation and the strains had indistinguishable disease progress curves. At $20^{\circ} \mathrm{C}$, UW551 remained highly virulent and killed all inoculated plants, although it took 3 weeks

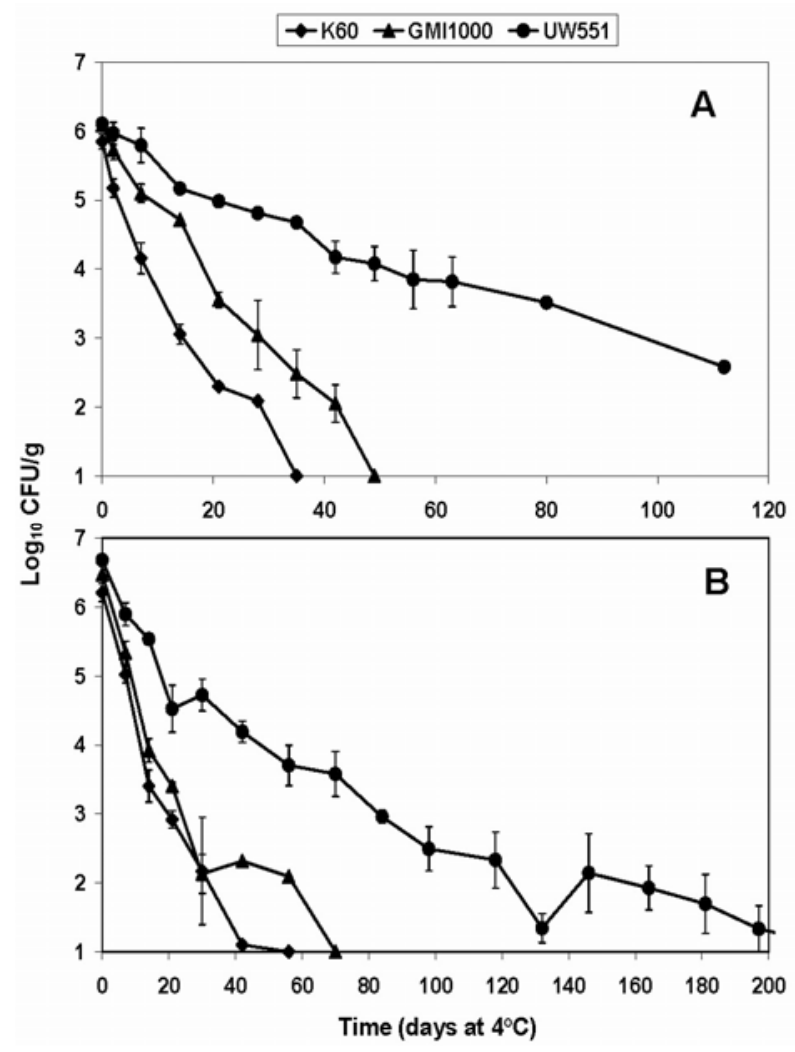

Fig. 3. Survival of Ralstonia solanacearum strains in potato tubers at $4^{\circ} \mathrm{C}$. Race 3 biovar 2 strain UW551, tropical strain GMI1000, and endemic North American strain K60 were inoculated into potato minitubers A, cv. Russett Norkotah and B, cv. Shepody. Tubers were injected to an initial cell density of 1 to $2 \times 10^{6} \mathrm{CFU} /$ tuber and were immediately stored at $4^{\circ} \mathrm{C}$. Culturable cells were enumerated at regular intervals by dilution plating on casamino acidspeptone-glucose agar plates. Two or three tubers were sampled per strain per time point. Detection limit was $10 \mathrm{CFU} / \mathrm{g}$ of potato tissue. This experiment was repeated twice; typical results are shown. Points represent means of technical replicates; bars indicate standard error. rather than 2 weeks to reach full mortality. In striking contrast, at $20^{\circ} \mathrm{C}$, tropical strain GMI1000 killed barely half the plants 1 month after inoculation. Thus, there was no difference in virulence on tomato plants between GMI1000 and UW551 at a lowland tropical soil temperature $(P=0.87)$ (Table 2$)$ while UW551 was much more virulent than GMI1000 $(P=0.017)$ at a temperature typical of potato culture in the highland tropics.

\section{DISCUSSION}

We undertook these experiments to better understand the ability of $R$. solanacearum R3bv2 strains to survive and cause disease in cool temperate conditions where other $R$. solanacearum strains do not threaten crops. Collectively, our data indicate that R3bv2 has no special adaptation to survive cold temperatures in water under controlled conditions, nor did it grow much faster than a tropical strain when cultured at the moderately cool temperature of $20^{\circ} \mathrm{C}$. However, the presence of host plant tissue appears to mediate distinctive cold adaptation for R3bv2, both in terms of survival at near-freezing temperatures and ability to wilt plants at cool temperatures.

$R$. solanacearum is often spread through waterways by flooding and irrigation, and the bacterium can survive for years in pure water in the laboratory $(8,23,39)$. It was possible that R3bv2 is a successful temperate pathogen because it is better able to persist in cold water than tropical strains. Therefore, we measured survival of diverse $R$. solanacearum strains over time in water microcosms maintained at $4^{\circ} \mathrm{C}$. Although R3bv2 is supposed to be more cold tolerant than other $R$. solanacearum strains (15, 23,43), we found that endemic strains from the southeastern United States actually survived longer in water at $4^{\circ} \mathrm{C}$ than R3bv2 strains. The southeastern U.S. isolates used in this study, like all native North American strains characterized to date, belong to the sequevar 7 subgroup. These strains, historically known as race 1 biovar 1, behaved similarly and all remained culturable in cold water several weeks longer than the R3bv2 strains. Although the R3bv2 strains tested were isolated from four continents, they are all in sequevar 1 and had similar survival in water, in keeping with their likely clonal nature. The group $\mathrm{C}$ tropical isolates came from four different sequevars but had similarly brief survival in $4^{\circ} \mathrm{C}$ water. We conducted these experiments in pure water to isolate the effects of temperature on survival from those of microbial competition or predation in water. This limits the extent to which these results can be extrapolated to the field. However, previous studies with nonsterile natural agricultural drainage water suggest that R3bv2 populations decline even faster in the presence of other microbes at $4^{\circ} \mathrm{C}$, becoming undetectable in only 30 days (51). This is consistent with field observations in rivers in the United Kingdom and with data showing that, in the absence of host plants, $R$. solanacearum strains are poor competitors in soil and water microbial communities $(2,10,17,20,23)$. We did not

TABLE 2. Results from repeated-measures analyses of variance of Ralstonia solanacearum strain growth in culture and virulence on tomato at 20 and $28^{\circ} \mathrm{C}$

\begin{tabular}{lllcc}
\hline Experiment & \multicolumn{1}{c}{ Effect } & $\mathrm{df}^{\mathrm{a}}$ & $F$ value & $P$ value $^{\mathrm{b}}$ \\
\hline Growth in culture & & & & \\
At $20^{\circ} \mathrm{C}$ & Strain & 1 & 137.21 & $<0.0001^{* * *}$ \\
& Rep (strain) & 2 & 3.04 & $0.076 \mathrm{~ns}$ \\
& Time $\times$ strain & 8 & 11.36 & $0.0007 * * *$ \\
At $28^{\circ} \mathrm{C}$ & Strain & 1 & 1.193 & $0.293 \mathrm{~ns}$ \\
& Rep (strain) & 2 & 2.267 & $0.140 \mathrm{~ns}$ \\
Virulence on tomato & Time $\times$ strain & 8 & 9.84 & $0.0034^{* *}$ \\
At $20^{\circ} \mathrm{C}$ & Strain & 1 & 15.46 & $0.017 * *$ \\
At $28^{\circ} \mathrm{C}$ & Strain & 1 & 0.030 & $0.87 \mathrm{~ns}$ \\
\hline
\end{tabular}

a df, degrees of freedom.

b Symbols: $* * *$ and $* *=P<0.0001$ and 0.001 , respectively; $\mathrm{ns}=$ not significant $(P>0.05)$. 
measure the effects of temperature and plant tissue on soil survival but data from numerous previous studies suggest that $R$. solanacearum, especially R3bv2, survives long-term in natural soil primarily in association with plant debris $(17-20,22,40,52)$.

We found that R3bv2 strain UW551, southeastern U.S. strain $\mathrm{K} 60$, and tropical strain GMI1000 all began to enter a VBNC state after 4 to 6 weeks in water at $4^{\circ} \mathrm{C}$. These cells did not grow on unamended rich medium plates but some did grow on plates amended with catalase. It was previously observed that addition of catalase increased the number of colonies formed by $R$. solanacearum cells following cold storage (54), possibly because stressed cells are less able to detoxify the hydrogen peroxide present in autoclaved rich medium. Cells also had intact membranes when examined under a microscope following live/dead staining. Previous studies documented that several R3bv2 isolates became VBNC over time in $4^{\circ} \mathrm{C}$ water, and there is some evidence that exposure to copper can trigger VBNC in American sequevar 7 strain AW1, although copper did not have this effect on R3bv2 strain IPO1609 $(3,21,51,54)$. VBNC has been described as a survival or resting state for bacteria, but it may also be a transition stage between life and death $(32,36,53)$. VBNC cells of human pathogens such as Escherichia coli and Vibrio cholerae can be revived by passage through a host (36). The epidemiological significance of VBNC $R$. solanacearum cells is unknown, because it is unclear how frequently or even if VBNC cells can revive and attack plants (53). Our data confirm that cold triggers $R$. solanacearum cells to become VBNC in large numbers, with almost $10^{5}$ live-staining R3bv2 cells per milliliter present after 114 days when no detectable CFU remained. We found that these cells are not likely to resuscitate and grow in plants, consistent with a previous report (54). Studies are needed to determine the prevalence of VBNC R3bv2 cells in naturally infested environments because these cells are invisible to the culture-dependent detection methods used in most previous studies. More extensive, carefully controlled experiments are also needed to conclusively determine whether VBNC $R$. solanacearum cells can revive and pose a risk to crops.

In contrast to our finding that endemic U.S. $R$. solanacearum strains survived longer than R3bv2 strains in water at $4^{\circ} \mathrm{C}, \mathrm{R} 3 \mathrm{bv} 2$ strain UW551 remained detectable significantly longer than tropical or native North American strains in potato tubers at $4^{\circ} \mathrm{C}$. This result is epidemiologically relevant because potato seed tubers are typically stored at 4 to $5^{\circ} \mathrm{C}$ for $\approx 6$ months, and latently infected seed tubers are a common source of potato brown rot outbreaks $(1,35)$. However, although GMI1000 and K60 rapidly became unculturable in potato tubers, these strains could still be detected following prolonged enrichment culture in rich broth. This may be the result of surviving culturable cells that were too few to be detected by dilution plating (our detection limit was 10 cells/g of potato tissue). The enrichment method does not allow quantification of recovered cells. Alternatively, $R$. solanacearum cells may have entered a reversible VBNC state after months of storage in potato tubers at $4^{\circ} \mathrm{C}$. These preliminary results suggest a potential risk of resuscitation of VBNC cells in potato tubers under favorable conditions. Experiments are needed to determine the probability that potato tubers containing VBNC cells could cause latent or active infections under field conditions.

The most direct explanation for the differential pathogenic aggressiveness of R3bv2 in temperate climates is that this subgroup can multiply faster at cooler temperatures than tropical strains. We tested this hypothesis by measuring the growth rate of tropical strain GMI1000 and R3bv2 strain UW551 in minimal medium under cool and warm conditions. There was no difference in doubling time or overall growth curve in liquid minimal medium between R3bv2 and tropical strain GMI 1000 at $28^{\circ} \mathrm{C}$ and only a minor difference between the strains at $20^{\circ} \mathrm{C}$. This result is consistent with a previous report that $\mathrm{K} 60$ and R3bv2 strain UW257 grew similarly in culture at $16^{\circ} \mathrm{C}$, even though the R3bv2 strain was more virulent on potato at $16^{\circ} \mathrm{C}$ than $\mathrm{K} 60$ (6). This finding demonstrates that R3bv2 is not more virulent in cool climates simply because it grows faster than tropical strains at low

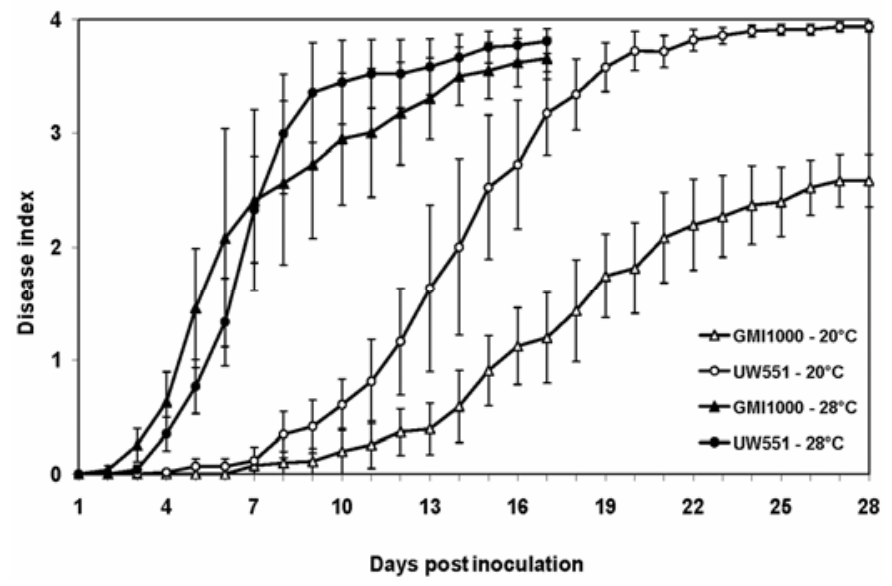

Fig. 5. Virulence of tropical and cool-temperate Ralstonia solanacearum strains on tomato plants at 20 and $28^{\circ} \mathrm{C}$. Sixteen-day-old unwounded tomato plants (cv. Bonny Best) were inoculated by pouring bacteria onto the soil to a final concentration about $1 \times 10^{8} \mathrm{CFU} / \mathrm{g}$ soil. Plants were rated daily on a disease index scale of 0 to 4 where 0 indicated healthy and 4 indicated $100 \%$ wilted. Each point represents the mean disease index for three independent experiments containing 20 plants for each; bars indicate standard error.
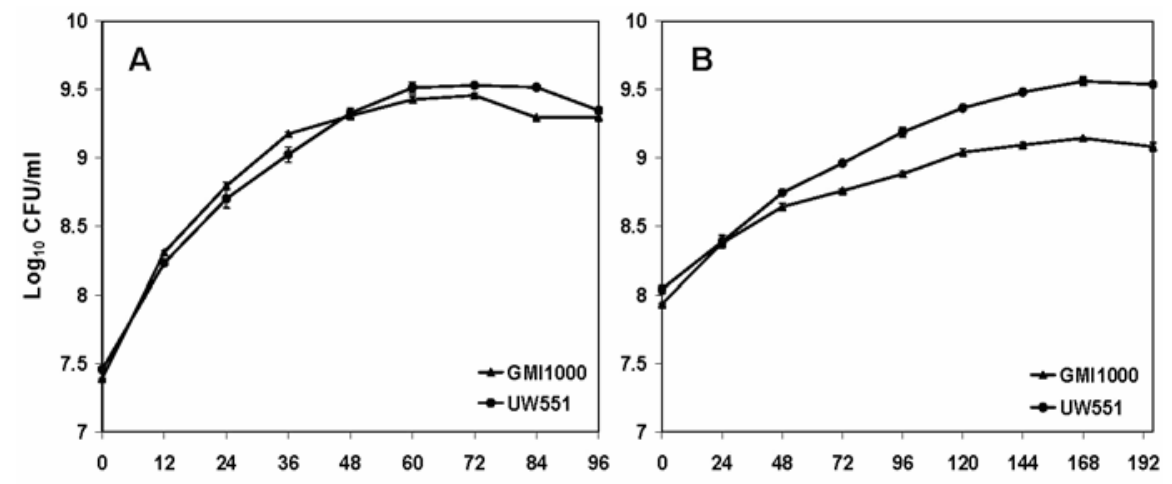

Hours post inoculation

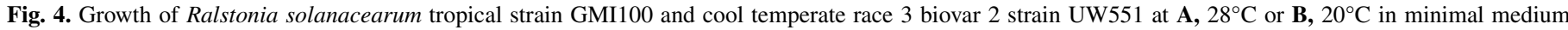

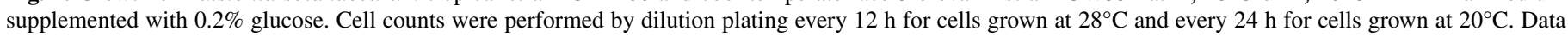
shown reflect the average of three experiments, each containing three cell count plates per strain per time point; bars indicate standard error of the mean. 
temperatures. It has been suggested that R3bv2 strains have a lower optimal growth temperature in culture than other $R$. solanacearum strains (15) but we found that UW551, like GMI1000 and $\mathrm{K} 60$, grew faster at $28^{\circ} \mathrm{C}$ than at cooler temperatures (C. Allen, unpublished data). Collectively, these results show that differential growth rates at cooler temperatures are unlikely to fully explain the behavioral differences between the strains in the field.

Our experiments with tomato inoculated in a controlled environment are consistent with extensive field observations that R3bv2 is more virulent at cool temperatures than tropical strains like GMI1000 (23). Although both strains killed plants at similar rates at $28^{\circ} \mathrm{C}$, UW551 was a much more effective pathogen at $20^{\circ} \mathrm{C}$, a typical temperature on potato farms in the highland tropics. If R3bv 2 is as virulent as a tropical strain at $28^{\circ} \mathrm{C}$, why isn't R3bv2 a serious problem in the lowland tropics? Our growth-chamber experiments measured the effects of temperature in isolation, apart from other factors affecting pathogen success in natural agroecosystems. It is possible that R3bv2 strains do not compete well with tropical soil microflora or tolerate physical conditions of tropical soils. It would be interesting to measure the competitive ability of GMI1000 and UW551 to colonize tomato plants following dual inoculation under various physical conditions.

The special quarantine status of R3bv2 is based on concern that, if this strain becomes established in North America, it could cause serious crop losses in cool temperate agriculture. However, it is not clear whether the success of R3bv2 in the highland tropics, where temperatures are cool year-round but rarely fall below freezing for extended periods, translates to an ability to persist and cause disease in northern temperate zones. Additional studies are needed to determine whether R3bv2 can survive a typical winter in North American potato-growing regions, where average temperatures may remain below $-10^{\circ} \mathrm{C}$ for weeks at a time. R3bv2 has survived the more moderately cold winters of northern Europe, although some evidence suggests that it does so by associating with host plants like $S$. dulcamara (13). Moreover, although R3bv2 strains are still present in soils and waterways of northern Europe 13 years after their initial discovery, bacterial wilt has not caused significant crop losses there $(3,5,12)$.

Our finding that differences in virulence and survival between R3bv2 and tropical $R$. solanacearum strains can be measured only in planta suggests that the epidemiological difference between these two groups cannot be explained by typical bacterial cold adaptations such as increased membrane fluidity or chaperone proteins that stabilize proteins or nucleic acids at low temperatures (33), unless these adaptations were specifically triggered by a plant host signal. A more likely hypothesis is that plant-induced cold adaptation traits are encoded by some of the $\approx 400$ genes that are uniquely present in the UW551 genome relative to that of GMI1000 (16). Alternatively, genes that are present in both strains may be induced under cold conditions only in UW551. In planta gene expression microarray experiments are currently underway to distinguish among these alternatives and to gain a more mechanistic understanding of how low temperatures affect bacterial wilt virulence in tropical and R3bv2 strains.

\section{ACKNOWLEDGMENTS}

This research was supported by the United States Department of Agriculture (USDA) Agricultural Research Service Floral and Nursery Crops Industry Task Force Initiative, USDA-CSREES Plant Biosecurity award 07-55605-17843, and the University of Wisconsin-Madison College of Agricultural and Life Sciences. We thank R. Spear for valuable help with microscopy, D. Waller for statistical advice, M. Klopmeyer (Ball FloraPlant) and P. Berger (USDA-APHIS-PPQ-CPHST) for useful discussions, and D. Sklarczyk (Sklarczyk Seed Farm LLC) and Agdia Inc. (Elkhart, IN) for donated research materials.

\section{LITERATURE CITED}

1. Allen, C., Kelman, A., and French, E. R. 2001. Brown rot of potatoes. Pages 11-13 in: Compendium of Potato Diseases. W. R. Stevenson, R. Loria, G. D. Franc, and D. P. Weingartner, eds. American Phytopathological Society, St. Paul, MN.

2. Alvarez, B., Lopez, M., and Biosca, E. 2007. Influence of native microbiota on survival of Ralstonia solanacearum phylotype II in river water microcosms. Appl. Environ. Microbiol. 73:7210-7217.

3. Alvarez, B., Lopez, M., and Biosca, E. 2008. Survival strategies and pathogenicity of Ralstonia solanacearum phylotype II subjected to prolonged starvation in environmental water microcosms. Microbiology 154:3590-3598.

4. Boucher, C., Barberis, P., Trigalet, A., and Demery, D. 1985. Transposon mutagenesis of Pseudomonas solanacearum: isolation of Tn5-induced avirulent mutants. J. Gen. Microbiol. 131:2449-2457.

5. Caruso, P., Paloma, J. L., Bertolini, E., Álvarez, B., López, M. M., and Biosca, E. G. 2005. Seasonal variation of Ralstonia solanacearum biovar 2 populations in a Spanish river: Recovery of stressed cells at low temperature. Appl. Environ. Microbiol. 61:140-148.

6. Ciampi, L., and Sequeira, L. 1980. Influence of temperature on virulence of race 3 strains of Pseudomonas solanacearum. Am. Potato J. 57:307-317.

7. Ciampi, L., Sequeira, L., and French, E. R. 1980. Latent infection of potato tubers by Pseudomonas solanacearum. Am. Potato J. 57:377-386.

8. Denny, T. P. 2006. Plant pathogenic Ralstonia species. Pages 573-644 in: Plant-Associated Bacteria. S. S. Gnanamanickam, ed. Springer Publishing, Dordrecht, The Netherlands.

9. Denny, T. P., Makini, F. W., and Brumbley, S. M. 1988. Characterization of Pseudomonas solanacearum Tn5 mutants deficient in extracellular polysaccharide. Mol. Plant-Microbe Interact. 1:215-223.

10. Elphinstone, J., Stanford, H. M., and Stead, D. 1998. Detection of Ralstonia solanacearum in potato tubers, Solanum dulcamara, and associated irrigation water. Pages 133-139 in: Bacterial Wilt Disease: Molecular and Ecological Aspects. P. Prior, C. Allen, and J. Elphinstone, eds. Springer, Berlin.

11. Elphinstone, J. G. 1996. Survival and possibilities for extinction of Pseudomonas solanacearum (Smith) Smith in cool climates. Potato Res. 39:403-410.

12. Elphinstone, J. G. 2005. The current bacterial wilt situation: a global overview. Pages 9-28 in: Bacterial Wilt: The Disease and the Ralstonia solanacearum Species Complex. C. Allen, P. Prior, and A. C. Hayward, eds. American Phytopathological Society, St. Paul, MN.

13. Elphinstone, J. G., Stanford, H. M., and Stead, D. E. 1998. Survival and transmission of Ralstonia solanacearum in aquatic plants Solanum dulcamara and associated surface water in England. OEPP Bull. 28:9394.

14. Fegan, M., and Prior, P. 2005. How complex is the "Ralstonia solanacearum species complex"? Pages 449-461 in: Bacterial Wilt Disease and the Ralstonia solanacearum species complex. C. Allen, P. Prior, and A. C. Hayward, eds. American Phytopathological Society, St. Paul, MN.

15. French, E. R. 1986. Interactions between strains of Pseudomonas solanacearum, its hosts, and the environment. Pages 99-104 in: Bacterial Wilt Disease in Asia and the South Pacific. G. J. Persley, ed. Australian Centre for International Agricultural Research, Canberra, Australia.

16. Gabriel, D. W., Allen, C., Schell, M., Denny, T. P., Greenberg, J. T., Duan, Y. P., Flores-Cruz, Z., Huang, Q., Clifford, J. M., Presting, G., González, E. T., Reddy, J., Elphinstone, J., Swanson, J., Yao, J., Mulholland, V., Liu, L., Farmerie, W., Patnaikuni, M., Balogh, B., Norman, D., Alvarez, A., Castillo, J. A., Jones, J., Saddler, G., Walunas, T., Zhukov, A., and Mikhailova, N. 2006. Identification of open reading frames unique to a select agent: Ralstonia solanacearum race 3 biovar 2. Mol. Plant-Microbe Interact. 19:69-79.

17. Graham, J., Jones, D. A., and Lloyd, A. B. 1979. Survival of Pseudomonas solanacearum Race 3 in plant debris and in latently infected potato tubers. Phytopathology 69:1100-1103.

18. Graham, J., and Lloyd, A. B. 1979. Survival of potato strain (race 3) of Pseudomonas solanacearum in the deeper soil layers. Aust J. Agric. Res. 30:489-496.

19. Granada, G. A., and Sequeira, L. 1983. Survival of Pseudomonas solanacearum at low temperature. Fitopatologia 18:22-24.

20. Granada, G. A., and Sequeira, L. 1983. Survival of Pseudomonas solanacearum in soil, rhizosphere, and plant roots. Can. J. Microbiol. 29:433-440.

21. Grey, B. E., and Steck, T. R. 2001. The viable but nonculturable state of Ralstonia solanacearum may be involved in long-term survival and plant infection. Appl. Environ. Microbiol. 67:3866-3872.

22. Harrison, D. E. 1961. Bacterial wilt of potatoes I. Field symptoms of the disease and studies on the causal organism, Pseudomonas solanacearum var. asiaticum. Aust. J. Agric. Res. 12:854-871. 
23. Hayward, A. C. 1991. Biology and epidemiology of bacterial wilt caused by Pseudomonas solanacearum. Annu. Rev. Phytopathol. 29:65-87.

24. Hayward, A. C. 1994. Systematics and phylogeny of Pseudomonas solanacearum and related bacteria. Pages 123-135 in: Bacterial Wilt: The Disease and its Causative Agent, Pseudomonas solanacearum. A. C. Hayward and G. L. Hartman, eds. CAB International, Wallingford, UK.

25. Hendrick, C., and Sequeira, L. 1984. Lipopolysaccharide-defective mutants of the wilt pathogen Pseudomonas solanacearum. Appl. Environ. Microbiol. 48:94-101.

26. Janse, J. D., Beld, H. E. v. d., Elphinstone, J., Simpkins, S., Tjou-TamSin, N. A. A., and Vaerenbergh, J. v. 2004. Introduction to Europe of Ralstonia solanacearum biovar 2, race 3 in Pelargonium zonale cuttings. J. Plant Pathol. 86:147-155.

27. Ji, P., Allen, C., Sanchez-Perez, A., Yao, J., Elphinstone, J., Jones, J., and Momol, T. 2007. New diversity and diagnostic challenges associated with Ralstonia solanacearum strains in Florida. Plant Dis. 91:195-203.

28. Kang, Y., Huang, J., Mao, G., He, L., and Schell, M. A. 1994. Dramatically reduced virulence of mutants of Pseudomonas solanacearum defective in export of extracellular proteins across the outer membrane. Mol. Plant-Microbe Interact. 7:370-377.

29. Kelman, A. 1954. The relationship of pathogenicity of Pseudomonas solanacearum to colony appearance in a tetrazolium medium. Phytopathology 44:693-695.

30. Kim, S. H., Olson, T. N., Schaad, N. W., and Moorman, G. W. 2003. Ralstonia solanacearum race 3 , biovar 2 , the causal agent of brown rot of potato, identified in geranium in Pennsylvania, Delaware, and Connecticut. Plant Dis. 87:450.

31. Lambert, C. D. 2002. Agricultural Bioterrorism Protection Act of 2002: Possession, Use, and Transfer of Biological; Agents and Toxins; Interim and Final Rule. (7 CFR Part 331). Federal Register 67:76908-76938.

32. McDougald, D., Rice, S. A., Weichart, D., and Kjelleberg, S. 1998. Nonculturability: Adaptation or debilitation? FEMS Microbiol. Ecol. 25:1-9.

33. Phadtare, S. 2004. Recent developments in bacterial cold-shock response. Curr. Issues Mol. Biol. 6:125-136.

34. Pradhanang, P. M., Elphinstone, J. G., and Fox, R. T. V. 2000. Identification of crop and weed hosts of Ralstonia solanacearum biovar 2 in the hills of Nepal. Plant Pathol. 49:403-413.

35. Priou, S., Gutarra, L., and Aley, P. 2006. Sensitive detection of Ralstonia solanacearum in soil: A comparison of different detection techniques. Plant Pathol. 49:414-422.

36. Roszak, D. B., and Colwell, R. R. 1987. Survival strategies of bacteria in the natural environment. Microbiol. Rev. 51:365-379.

37. Salanoubat, M., Genin, S., Artiguenave, F., Gouzy, J., Mangenot, S., Arlat, M., Billault, A., Brottier, P., Camus, J., Cattolico, L., Chandler, M., Choisne, N., Claudel-Renard, C., Cunnac, S., Demange, N., Gaspin, C., Lavie, M., Moisan, A., Robert, C., Saurin, W., Schiex, T., Siguier, P., Thebault, P., Whalen, M., Wincker, P., Levy, M., Weissenbach, J., and Boucher, C. A. 2002. Genome sequence of the plant pathogen Ralstonia solanacearum. Nature 415:497-502.

38. Sanchez-Perez, A., Mejia, L., Fegan, M., and Allen, C. 2008. Diversity and distribution of Ralstonia solanacearum strains in Guatemala and rare occurrence of tomato fruit infection. Plant Pathol. 57:320-331.

39. Schaad, N. W., Jones, J. B., and Chun, W. 2001. Laboratory Guide for the Identification of Plant Pathogenic Bacteria. American Phytopathological Society, St. Paul, MN.

40. Shamsuddin, N., Lloyd, A. B., and Graham, J. 1978. Survival of the potato strain of Pseudomonas solanacearum in soil. J. Aust. Inst. Agric. Sci. 44:212-215

41. Smith, J., Offord, L., Holderness, M., and Saddler, G. S. 1995. Genetic diversity of Burkholderia solanacearum (synonym Pseudomonas solanacearum) Race 3 in Kenya. Appl. Environ. Microbiol. 61:4263-4268.

42. Strider, D. L., Jones, R. K., and Haygood, R. A. 1981. Southern wilt of geranium caused by Pseudomonas solanacearum. Plant Dis. 65:52-53.

43. Swanepoel, A. E. 1990. The effect of temperature on the development of wilting and on progeny tuber infection of potatoes inoculated with South African strains of biovar 2 and 3 of Pseudomonas solanacearum. Potato Res. 33:287-290.

44. Swanson, J. K., Montes, L., Mejia, L., and Allen, C. 2007. Detection of latent infections of Ralstonia solanacearum race 3 biovar 2 in geraniums. Plant Dis. 91:828-834.

45. Swanson, J. K., Yao, J., Tans-Kersten, J. K., and Allen, C. 2005. Behavior of Ralstonia solanacearum race 3 biovar 2 during latent and active infection of geranium. Phytopathology 95:136-143.

46. Tans-Kersten, J., Guan, Y., and Allen, C. 1998. Ralstonia solanacearum pectinmethylesterase is required for growth on methylated pectin but not for bacterial wilt virulence. Appl. Environ. Microbiol. 64:4918-4923.

47. Thurston, H. D. 1963. Bacterial wilt of potatoes in Columbia. Am. Potato J. 40:381-390.

48. Tung, P. X., Rasco, E. T., VanderZaag, P., and Schmiediche, P. 1990. Resistance to Pseudomonas solanacearum in the potato: II. Aspects of host-pathogen-environment interaction. Euphytica 45:211-215.

49. Tusiime, G., Adipala, E., Opio, F., and Bhagsari, A. S. 1998. Weeds as latent hosts of Ralstonia solanacearum in highland Uganda: implications to development of an integrated control package for bacterial wilt. In: Bacterial Wilt Disease: Molecular and Ecological Aspects. P. Prior, C. Allen, and J. Elphinstone, eds. Springer Verlag, Berlin.

50. van der Wolf, J. M., Bonants, P. J. M., Smith, J. J., M. Hagenaar, M., Nijhuis, E., Beckhoven, J. R. C. M. V., Saddler, G. S., Trigalet, A., and Feuillade, R. 1998. Genetic diversity of Ralstonia solanacearum race 3 in Western Europe determined by AFLP, RC-PFGE, and Rep-PCR. Pages 44-49 in: Bacterial Wilt Disease: Molecular and Ecological Aspects. P. Prior, C. Allen, and J. G. Elphinstone, eds. Springer Verlag, Berlin.

51. van Elsas, J. D., Kastelein, P., de Vries, P. M., and van Overbeek, L. S. 2001. Effects of ecological factors on the survival and physiology of Ralstonia solanacearum bv. 2 in irrigation water. Can. J. Microbiol. 47:842-854.

52. van Elsas, J. D., Kastelein, P., van Bekkum, P., van der Wolf, J. M., de Vries, P. M., and van Overbeek, L. S. 2000. Survival of Ralstonia solanacearum biovar 2 , the causative agent of potato brown rot, in field and microcosm soils in temperate climates. Phytopathology 90:13581366.

53. van Elsas, J. D., van Overbeek, L. S., and Trigalet, A. 2005. The viablebut-nonculturable state in Ralstonia solanacearum: is there a threat to our strategic concepts? Pages 103-119 in: Bacterial Wilt Disease and the Ralstonia solanacearum Species Complex. C. Allen, P. Prior, and A. C. Hayward, eds. American Phytopathological Society, St. Paul, MN.

54. van Overbeek, L. S., Bergervoet, J. H., Jacobs, F. H., and van Elsas, J. D. 2004. The low-temperature-induced viable-but-nonculturable state affects the virulence of Ralstonia solanacearum biovar 2. Phytopathology 94:463-469.

55. Wenneker, M., Verdel, M. S. W., Groeneveld, R. M. W., Kempenaar, C., Beuningen, A. R. V., and Janse, J. D. 1999. Ralstonia (Pseudomonas) solanacearum race 3 (biovar 2) in surface water and natural weed hosts: First report on stinging nettle (Urtica dioica). Eur. J. Plant Pathol. 105:307-315.

56. Williamson, L., Hudelson, B. D., and Allen, C. 2002. Ralstonia solanacearum strains isolated from geranium belong to race 3 and are pathogenic on potato. Plant Dis. 86:987-991. 